\title{
Experimental Study of Middle-term Training in Social Cognition in Preschoolers
}

\author{
Marine Houssa $^{1}$, Nathalie Nader-Grosbois ${ }^{1}$ \\ ${ }^{1}$ Université catholique de Louvain, Belgium \\ Correspondence: Marine Houssa, Université catholique de Louvain, Belgium
}

Received: July 27, 2015 Accepted: August 17, $2015 \quad$ Online Published: October 9, 2015

doi:10.11114/jets.v4i1.972 URL: http://dx.doi.org/10.11114/jets.v4i1.972

\begin{abstract}
In an experimental design, we examined the effects of middle-term training in social information processing (SIP) and in Theory of Mind (ToM) on preschoolers' social cognition and social adjustment.

48 preschoolers took part in a pre-test and post-test session involving cognitive, socio-cognitive and social adjustment (direct and indirect) measures. They were allocated at random to an experimental group (subgroups of 4 children attended 15 45-minute sessions in which they received ToM and SIP training using educational materials) or a control group (free play sessions).

The results showed that each group improved in direct measures of social cognition. The experimental group was significantly better at the SIP task in post-test than the control group. Significant correlations were obtained between individual and family characteristics and direct measures. Furthermore, regression analyses showed that, after controlling for pre-test result, SIP measures in post-test were significantly predicted by pre-test results and group condition.

This study could help professionals and parents by providing them with some basis for early training exercises that can induce an improvement in SIP competences in preschoolers.
\end{abstract}

Keywords: theory of mind, social information processing, social problem solving, training, preschoolers

\section{Introduction}

Social adjustment of preschoolers and prevention of externalizing behavior (EB) disorders are matters of some importance in mental health and education. Identifying risks of social maladjustment and EB as soon as possible and intervening adequately could help children to adapt to different environments; that is, encouraging better social adjustment could be useful before primary school entry. In the present study, we tested the effects of middle-term experimental training on the level of social cognition competences in preschoolers. Furthermore, we examined the potential impact of this training on their social adjustment.

In developmental psychology, several models have emerged to explain social adjustment difficulties in children. Amongst them, the Social Information Processing (SIP) and Theory of Mind (ToM) models may offer a suitable basis for explaining the development of social competences or accounting for possible social difficulties in children.

Preschoolers understand some mental states such as emotions, beliefs, desires, and intentions, and are able to infer the mental states of others (Deneault \& Ricard, 2013; Wellman, 1991). Children gradually become able to recognize desires and emotional expressions, to predict emotions according to social situations, to predict social behavior according to felt emotions (corresponding to 'affective' mental states), but also to adopt the visual perspective of others, to understand their beliefs and false beliefs (corresponding to 'cognitive' mental states). According to the Vygotskian ToM conception, sharing knowledge and explanations about mental states can help children's development of ToM (Astington, 1996).

The more children gain an understanding of positive and negative emotions, the better adapted their social behavior becomes (see notably, Deneault \& Ricard, 2013; Denham et al., 2003). In at-risk children, deficits in ToM are reported in the recognition of emotions (Blair \& Coles, 2000), but also in the understanding of causes and consequences of emotions (Hughes, Dunn, \& White, 1998) and of beliefs (Fahie \& Symons, 2003; Walker, 2005). Finally, we know that deficits in the recognition of mental states could be responsible for social adjustment difficulties (Deneault \& Ricard, 2013; Eisenberg et al., 1997) because of bias in the way children perceive social situations. 
In addition, Crick and Dodge (1994) have developed a functional SIP model to explain how children cognitively process critical social situations (i.e. provocation, ambiguity, conflict) and how they solve social problems. In a social situation, six steps are mobilized: they encode other people's social cues (a), interpret social cues (b), clarify goals (c), access possible responses or build a response (d), make a response decision (e) and enact the behavior (f) (Crick \& Dodge, 1994),

In children with - or at-risk of developing - EB disorders or social adjustment difficulties, deficits are postulated in each of the six steps of SIP (Crick \& Dodge, 1994; Dodge \& Crick, 1990; Dodge \& Pettit, 2003) and these get worse with time (Dodge et al., 2003). Consequently, in these children, deficits in social problem solving are also postulated (Pettit, Dodge, \& Brown, 1988) because they have difficulties in spotting relevant social cues and in judging whether or not other people's social behavior is appropriate.

As aggressive children with distorted SIP (Crick \& Dodge, 1996) are regularly rejected by their peers, they have less opportunity for positive social interactions. Conversely, children using SIP appropriately are able to interact easily with peers, display prosocial behavior and are then able to be socially accepted by others (Yeates et al., 2007).

What are the main features and effects of training programs in social cognition? Several authors have devised short-term training and middle-term or long-term intervention programs in social cognition competences. Studies have reported an improvement in children's competence in ToM 'emotions' (Walker, 2005) and in ToM 'beliefs' after short-term training in small groups (Appleton \& Reddy, 1996; Howlin, Baron-Cohen, \& Hadwin, 2011) (see a detailed review in Houssa, Nader-Grosbois, \& Jacobs, 2014). In general, these studies involved only one mental state (emotion or belief).

The authors of PATHS (Domitrovich, Cortes, \& Greenberg, 2007), Strong Kids (Merrell, Juskelis, Tran, \& Buchanan, 2008), EBP (Izard et al., 2008), Incredible Years (Webster-Stratton \& Reid, 2008), KITS (Pears, Fisher, \& Bronz, 2007), ICPS (Shure \& Spivack, 1982), Second Step (Frey, Hirschstein, \& Guzzo, 2000), but also Bhavnagri and Samuels (1996) and Ornaghi, Brockmeier, and Grazzani (2014) have emphasized the effectiveness of middle-term or long-term interventions for preschoolers. Such interventions have combined various targets (emotional regulation, social problem solving, emotion comprehension, prevent EB disorders, etc.). Studies have been conducted with typically developing preschoolers (Bhavnagri \& Samuels, 1996; Domitrovich et al., 2007; Frey et al., 2000; Ornaghi et al., 2014), at-risk preschoolers (Izard et al., 2008; Merrell et al., 2008), and preschoolers with EB disorders (Pears et al., 2007; Shure \& Spivack, 1982; Webster-Stratton \& Reid, 2008).

Several methodological factors of those programs favor effective training in social cognition for preschoolers. When understanding of emotions and beliefs are investigated, the techniques are: social interactions and communication through language about emotions, beliefs, false beliefs, etc; explanation of the correct responses; differentiated immediate feedback; asking for a justification; conversations after reading illustrated scenarios; repetition of the task; etc. For social problem solving abilities, the techniques are: identification of emotional and social cues; social problem solving; discussion about critical social situations; corrective feedback; production of alternative solutions in critical social situations; etc.

The most widely used techniques are the generalization of concepts and immediate feedback, which appear to be effective. The most relevant point about the materials used is their wide variety (videos, pictures, books, puppets, music, etc.).

There is disparity in terms of some methodological aspects across programs. Firstly, the trainer's status varies: sessions have been administered by teachers (Domitrovich et al., 2007; Izard et al., 2008; Webster-Stratton \& Reid, 2008), teachers or parents (Frey et al., 2000; Shure \& Spivack, 1982), experimenter (Ornaghi et al., 2014; Pears et al., 2007) or teacher and experimenter (Bhavnagri \& Samuels, 1996; Merrell et al., 2008). Secondly, to measure the effect, researchers have used several instruments for emotions, social problem solving, EB and social adjustment. For example, Pears et al. (2007) only used other-reported measures, while others have only applied direct measures through tests (Bhavnagri \& Samuels, 1996). A further group of researchers have combined both methods of assessment (Domitrovich et al., 2007; Izard et al., 2008; Shure \& Spivack, 1982). The CBCL (Achenbach \& Rescorla, 2000) is the most widely used other-reported measure of EB.

Effects are observed in direct as well as other-reported measures. Some programs merely showed behavioral stability in the experimental group, while the control group deteriorated (Pears et al., 2007). Others (e.g. Izard et al., 2008) generated a significant decrease in maladapted behaviors. An improvement in SIP was obtained after a training program including stories of peer interactions (Bhavnagri \& Samuels, 1996).

There is also disparity in group size: from groups of three children (e.g. Pears et al., 2007) to an entire class (e.g. Izard et al., 2008). The duration and the timing of training sessions are different: from 15 sessions bi-weekly (e.g. Ornaghi et 
al., 2014) to 30 sessions during 30 weeks (e.g. Bhavnagri \& Samuels, 1996). Despite the variation in several methodological aspects, the literature shows that children's abilities are efficiently improved.

However, to our knowledge, no study has ever investigated the effect of middle-term training combining ToM and SIP models. Moreover, authors who provided training in emotional competences did not take into account other mental states which are more cognitive. In addition, the targets of these programs were general: they aimed for not only an improvement of social and cognitive competences, but also a broader set of targets (such as academic competences, inhibition, adjustment at school or language). Furthermore, in terms of inter-individual variability in children, these studies did not take into account personality factors or verbal and non-verbal intellectual level.

In a previous study, Houssa and colleagues (2014) examined the differentiated effects of two one-shot SIP and ToM training sessions on preschoolers. After one training session, they found some transfer effect (the ToM training group improved in ToM 'emotions' and in SIP and the SIP training group improved in ToM 'beliefs' and in SIP). Based on these results, and on the programs reported above, we know that social cognition abilities are 'trainable' in preschoolers and that these processes potentially interact with each other.

In the present study, we decided to implement a middle-term intervention to allow an impact on social adjustment, rejecting a long term intervention in order to prevent interference from other factors.

We predicted that (1a) children who benefited from training would have significantly better competence in ToM (i.e. affective and cognitive mental states) and SIP (i.e. social problem solving). A positive effect (1b) for social adjustment was also expected.

The second objective was to explore links between ToM, SIP abilities and adults' perception of children's social adjustment and EB in the pre-test session, taking individual characteristics into account. We predicted positive links between ToM and SIP abilities and chronological age (CA), intellectual quotient (IQ) (2a) and specific factors of personality (2b) and also between social cognition and social adjustment (2c). Finally, we hypothesized some links between several variables and EB. A positive link between CA and EB, a negative link between social cognition and EB, and links between the five factors of personality and EB were expected (2d). Regression analyses helped to explore these links.

\section{Method}

\subsection{Participants}

The participants were 48 children (13 boys and 35 girls). They were between 4 years and 5 years and 4 months old ( $M$ age $=55.7$ months, $\mathrm{SD}=4.4$ months). The level of education of mothers was indicated on a seven-point scale from low (elementary school not completed) to high (university), with a mean of 4.98 ( $\mathrm{SD}=1.51)$ (5 corresponded to 'short higher education'); for fathers, the mean was 4.32 ( $\mathrm{SD}=1.65)(4$ was equivalent to 'apprenticeship contract'). The families' monthly income was indicated on a nine-point scale from low (0-500 euros) to high (4000 euros or more), and the mean was 5.98 ( $\mathrm{SD}=1.97$ ), corresponding to $2500-3000$ euros a month.

Participants were recruited in French-speaking Belgian schools. Children were excluded if parents and teachers had ever reported problems with their behavior (our inclusion criterion was a score below 21 at the CBCL-corresponding to 'normal' level; Achenbach \& Rescorla, 2000), or in the case of developmental delay or intellectual disabilities. Information letters and consent forms were sent to parents.

\subsection{Procedure}

For the pre-test, three different tests were administered: four subscales of the WPPSI-III, ToM Task Battery and RES. Total administration time was approximately 60 minutes. Children were tested individually at school in a quiet room. Parents completed the ToMI, the EASE and the CBCL, and teachers completed the CBCL and the EBMCF. For the EB variable (CBCL), we took the mean of parents' and teachers' versions.

Then, children were randomly assigned to the experimental $(n=24)$ or to the control group $(n=24)$. In groups of 4 , children participated in 15 45-minute sessions held twice-weekly at school. Sessions were administered by two experimenters.

Finally, children were assessed in a post-test using the ToM Task Battery and RES. Again, parents completed some questionnaires (EASE and ToMI). As personality was regarded as stable, the EBMCF was not completed in post-test. Because of the school holidays, there were approximately 5 months between pre- and post-test.

\subsection{Instruments}

\subsubsection{Measures of Individual Characteristics}

Wechsler Intelligence Scales - third edition (Weschler, 2004) 
These scales were used in pre-test session to exclude possible mental retardation. They distinguish between verbal and non-verbal IQ. Verbal IQ is obtained by means of scores on two scales: "information" and "verbal reasoning". Performance IQ is obtained by means of the "matrix" and "block design" scales. The mean of each scale is 10, with a standard deviation of 3. We included children with a global score between 5.5 and 14.5 (1.5 SD). This global score was the mean of the four subscales.

Bipolar Rating Scales based on the Five Factor Model (EBMCF, Roskam, De Maere-Gaudissart, \& Vandenplas-Holper, 2000)

This questionnaire measures children's personality. It includes 25 items; five factors of personality for each factor in the model (extraversion, agreeableness, conscientiousness, emotional stability and openness). The factor analysis revealed the 5 expected factors, for which Cronbach's alpha was between .70 and .93 . Coefficients of test-retest stability were highly significant (Roskam et al., 2000).

Child Behavior Checklist (CBCL, Achenbach \& Rescorla, 2000)

The CBCL includes items to assess behavioral and emotional problems in children. In this study, we only used items related to EB to ensure that children were not too high on the EB scale. The 'Aggressive behavior' subscale and the 'Attention problems' subscale from the CBCL were summed to determine the 'Externalizing behavior' score. Internal consistency $(\alpha=.63-.86)$ and test-retest reliability $(r=.85)$ were satisfactory.

\subsubsection{Measures of Theory of Mind}

Theory of Mind Task Battery (Hutchins, Prelock, \& Chace, 2008)

The ToM Task Battery is composed of 15 test questions in 9 tasks. This test evaluates separate mental states but also the combination of mental states (e.g., desire-based emotion, perception-based belief, second-order false belief). This test was validated through test-retest reliability, internal consistency and external correlation (Nader-Grosbois \& Houssa, in preparation).

Theory of Mind Inventory - French version (ToMI, Hutchins, Prelock, \& Bonazinga, 2012) (translated by Houssa, Mazzone, \& Nader-Grosbois, 2014)

It measures caregivers' perceptions of children's ToM abilities. The ToMI is designed to identify caregivers' impressions of children's thoughts and feelings. It consists of 39 statements ranges from 0 to 20. Internal consistency $(\alpha$ $=.94)$ and test-retest reliability $(r=.86)$ are high (Houssa, Mazzone, et al., 2014).

\subsubsection{Measure of Social Information Processing}

Social problem solving task (RES, Barisnikov, Van der Linden, \& Hippolyte, 2004)

This task is used to assess SIP competences, i.e.to estimate the capacity of children to judge whether or not other people's social behavior is appropriate, and to determine the extent to which their judgment is based on a knowledge of conventional and/or moral rules. This task consists of showing 14 items (five appropriate and nine inappropriate social behaviors). Firstly, the child is asked whether the social behavior is appropriate or inappropriate; the maximum score is 28 points (judgment score). The second question assesses the identification of the target behavior. The child has to identify what is good or not in the picture; the maximum score is 14 (identification score). Finally, the third question (reasoning score) estimates the extent to which the judgment is justified by reference to social rules. Three levels of response are proposed for this question, corresponding to the award of 2, 5, and 7 points respectively. First, the descriptive level corresponds to a description of the situation. Second, the inter-subjective level reflects a position linked to social consciousness, but limited to an understanding of concrete aspects of the situation. Third, the conceptual level reflects social consciousness, a reference to social rules, and generalization. No points are given if a justification is inappropriate or not given. The maximum score for this third question is 98 and 140 for three questions. The inter-judge agreement was 98\% congruent (Hippolyte, Iglesias, Van der Linden, \& Barisnikov, 2010).

\subsubsection{Measure of Social Adjustment}

Social adjustment scales (EASE, Hughes, Soares-Boucaud, Hochman, \& Frith, 1997)

The EASE is a measure of adults' perceptions of children's socio-emotional adjustment competencies in daily life. It includes items relating to social competencies (non-ToM), but also items relating to children's mentalization capacities and perspective-taking abilities (ToM). For each item, caregivers/teachers have to indicate if the behavior is usual for their children. The two subscales had good internal consistency: Cronbach's alpha was .77 for the "ToM subscale", and .79 for the "No ToM subscale".

\subsection{Training Sessions}

In the experimental group, children received training in SIP and ToM competences. Sessions were constructed with 
reference to a theoretical background and on the basis of a hierarchical progression (from simple to complex abilities). The first 7 sessions dealt with ToM competences; the 7 following sessions dealt with SIP competences; the final session integrated all of the concepts. An appendix presents the objectives, activities and the techniques used.

The first basis for the training was the program of Howlin and colleagues (2011). It establishes a progression in the understanding of mental states. The levels for emotions are: (a) photographic facial recognition, (b) schematic facial recognition, (c) situation-based emotions, (d) desire-based emotions, and (e) belief-based emotions. For beliefs, the levels are: (a) simple perspective taking, (b) complex perspective taking, (c) seeing leads to knowing, (d) true belief/action prediction, and (e) false belief (Hadwin, Baron-Cohen, Howlin, \& Hill, 1996).

The second basis was the six steps of the SIP model (Crick \& Dodge, 1994): (a) encoding other people's social cues, (b) interpretation of social cues, (c) clarification of goals, (d) response access, (e) response decision, (f) behavioral enactment.

The third inspiration was the hierarchical levels of justification distinguished by Barisnikov et al. (2004) in the RES: (a) descriptive level (description of facts), (b) intersubjective level (position linked to social consciousness), and (c) conceptual level (make reference to a social rule or convention). On the basis of the child's level assessed by means of RES in pretest, the experimenter tries to elicit a more complex level of justification, by using the proximal zone of development conceptualized by Vygotsky (1978).

Children worked in groups because, as some researchers have recently suggested (e.g. Houssa, Nader-Grosbois, et al., 2014; Lecce, Bianco, Devine, Hughes, \& Banerjee, 2014; Ornaghi et al., 2014), they were able to help each other by completing each other's answers or correcting them, inducing socio-cognitive conflict which might help them with their thinking and highlighting the existence of various points of view on the same social situations. Furthermore, a speaking slot was applied.

The activities involved included sequences of play, pictures, video extracts, handling of objects, puppets, story reading, etc. Each session ended with a story dealing with an emotion, with a false belief or a social problem solving situation. Reading stories to children and talking about the protagonists' mental states and emotions seems to increase their social cognition level (Bhavnagri \& Samuels, 1996; Ornaghi et al., 2014).

Different types of material were included in each session, to ensure that they were adapted to the children's individual styles of perceptive and socio-perceptive processing, selective attention capacity, cognitive inhibition attention, and fatigue and were able to stimulate their interest. This variety of materials can help children to generalize and apply what they have learned in new situations.

Open-ended questions were asked to induce conversations, and feedback was provided as well as an explanation of the correct or expected response. Correct answers led to positive feedback, while incorrect answers elicited explanations about the correct response (differentiated immediate feedback). To promote the generalization of concepts, the experimenter reminded the general principle related to the task (such as the social rules that could be applied in this social situation).

The control children participated in groups in 1545 -minute free play sessions to control the familiarity effect of the experimenter. The experimenter avoided addressing SIP and ToM concepts.

\section{Results}

First, independent sample $t$-tests were conducted to check the equivalence between groups in pre-test. Then, to measure the effectiveness of the intervention, a repeated measure ANOVA was conducted on each measure with pre- and post-test scores as a within-group factor and groups as a between-participants factor. After that, intercorrelations in pre-test were tested. Finally, we conducted multiple regression analyses to examine which variables contributed to children's social cognition and social adjustment.

\subsection{Between Group Comparisons on Pre-test}

Table 1 presents means and standard deviations for all variables in the pre-test session for the control and the experimental group. Independent sample $t$-tests revealed no significant difference between groups. The groups could be considered as equivalent in pre-test except for one family characteristic: mothers in the experimental group had a significantly lower level of education than mothers in the control group.

\subsection{Effect of the Intervention}

\subsubsection{Theory of Mind}

As Table 1 shows, a repeated measure ANOVA revealed no significant pre/post-test effect for the ToM measures. Paired sample $t$-tests showed a pre/post-test effect in the experimental group for the ToM Task Battery, $t(23)=2.83, p=.001$, 
but also in the control group, $t(23)=3.79, p=.01$. Concerning the ToMI, paired sample t-tests revealed a pre/post-test effect in both groups; $t(23)=4.51, p=.046$ for the experimental group and $t(23)=2.12, p=.00$ in the control group.

\subsubsection{Social Information Processing}

A repeated measure ANOVA showed significant time by group interactions on the SIP measure in favor of the experimental group. This interaction is significant for the RES total $\left(F(1,23)=8.54, p=.005, \eta_{\mathrm{p}}^{2}=.16\right)$, for Question 3 of the $\operatorname{RES}\left(F(1,23)=9.10, p=.004, \eta_{\mathrm{p}}^{2}=.17\right)$, and for two levels of justification (wrong/no justification: $F(1,23)=$ $16.59, p=.00, \eta_{\mathrm{p}}^{2}=.27$ and inter-subjective level: $\left.F(1,23)=4.01, p=.051, \eta_{\mathrm{p}}^{2}=.08\right)$.

Significant group by time interactions were further analyzed by paired sample $t$-tests. Concerning the RES total, the experimental group significantly improved between pre- and post-test, $t(23)=11.77, p=.00$, which was also the case for the control group, $t(23)=5.20, p=.00$. For Question 3 of the RES, the experimental group significantly improved between pre- and post-test, $t(23)=10.98, p=.00$, which was also the case for the control group, $t(23)=4.77, p=.00$. Then, for the percentage of wrong answers/no justification, there were also significant improvements between pre- and post-test for the experimental group, $t(23)=-8.35, p=.00$, and the control group, $t(23)=3.37, p=.003$. Finally, for the percentage of the intersubjective level, there was also significant improvement between pre- and post-test for the experimental group, $t(23)=-7.70, p=.00$, and the control group, $t(23)=4.03, p=.001$.

\subsubsection{Social Adjustment}

A repeated measure ANOVA reveals no significant pre/post-test effect for the social adjustment measures. Nonetheless, paired sample $t$-tests showed a pre/post-test effect in the experimental group for the EASE non-ToM, $t(23)=2.04, p$ $=.05$, which was not the case for the control group, $t(23)=.51, p=.61$.

\subsection{Intercorrelations in Pre-test}

Table 2 presents intercorrelations between some pre-test variables. CA correlates negatively and significantly with 'consciousness', 'openness', and 'agreeableness' and positively and significantly with RES scores. The IQ is positively linked to 'openness', 'agreeableness', and 'extraversion', to the ToM Task Battery, to the EASE, to family income and to fathers' education level. 'Extraversion' is significantly and positively correlated with the ToMI. EB is negatively and significantly correlated with 'consciousness', 'openness', 'agreeableness' and 'emotional stability'. Social adjustment is positively linked to ToM Task Battery and ToMI, and family characteristics.

\subsection{Multiple Regression Analyses}

To investigate the extent to which individual characteristics and group condition contribute to children's social cognition and social adjustment, a hierarchical multiple regression analysis was conducted. In Model 1, pre-test results were entered so that this variable was controlled; in Model 2, pre-test results and individual characteristics (CA, IQ and personality factors) were entered; in Model 3, pre-test results, individual characteristics and group condition were entered.

As shown in Table 3, distinct independent predictors explained scores on social cognition measures. After controlling for pre-test result in ToM Task Battery and ToMI (Model 1), predictors entered in Models 2 and 3 were non-significant. After accounting for the pre-test result in RES (Model 1), the RES in post-test was predicted by Model 3 (24\% of the variance). It is important to note that pre-test result in RES and group condition are the only variables which made a contribution. After controlling for the pre-test result in social adjustment, Model 2 (CA and personality factors) accounted for $25 \%$ of the variance. For social adjustment, the variables which contribute in Model 2 were pre-test results, CA, agreeableness and extraversion. Predictors entered in the last model were non-significant for social adjustment. 
Table 1. Means and standard deviations for each group in pre-test and post-test session and between-group comparisons

\begin{tabular}{|c|c|c|c|c|c|c|c|c|c|c|c|}
\hline \multirow[b]{2}{*}{ Variables } & & \multicolumn{3}{|c|}{ Pretest session } & & \multicolumn{3}{|c|}{ Posttest session } & \multicolumn{3}{|c|}{$\begin{array}{c}\text { Analysis } \\
(F)\end{array}$} \\
\hline & & $\begin{array}{l}\text { Contro } \\
1 \text { group }\end{array}$ & $\begin{array}{l}\text { Experimenta } \\
1 \text { group }\end{array}$ & & & $\begin{array}{l}\text { Contro } \\
1 \text { group }\end{array}$ & $\begin{array}{l}\text { Experimenta } \\
1 \text { group }\end{array}$ & & & $\begin{array}{l}\text { Group by } \\
\text { time } \\
\text { interactio } \\
n \\
\end{array}$ & $\begin{array}{l}\text { Partia } \\
1 \text { Eta }^{2}\end{array}$ \\
\hline & & $\begin{array}{c}M \\
(\mathrm{SD})\end{array}$ & $M(\mathrm{SD})$ & $t$ & $\mathrm{D}$ & $\begin{array}{c}M \\
(\mathrm{SD})\end{array}$ & $M(\mathrm{SD})$ & $t$ & $\mathrm{D}$ & & \\
\hline $\begin{array}{l}\text { Sex } \quad(\% \\
\text { Male })\end{array}$ & & $25 \%$ & $29.2 \%$ & .32 & & $\cdot$ & . & . & . & & \\
\hline $\begin{array}{l}\mathrm{CA} \text { (in } \\
\text { months) }\end{array}$ & & $\begin{array}{l}56.58 \\
(5.17)\end{array}$ & $54.83(3.35)$ & -1.39 & $\begin{array}{l}.4 \\
0\end{array}$ & . & . & . & . & & \\
\hline IQ & & $\begin{array}{l}100.83 \\
(18.13)\end{array}$ & $\begin{array}{c}93.12 \\
(21.27)\end{array}$ & -1.35 & $\begin{array}{l}.3 \\
9\end{array}$ & . & . & . & . & & \\
\hline \multirow[t]{5}{*}{$\begin{array}{l}\text { Personalit } \\
\text { y }\end{array}$} & $\begin{array}{l}\text { Conscientiousness } \\
\text { a }\end{array}$ & $\begin{array}{c}6.07 \\
(2.09)\end{array}$ & $6.67(1.72)$ & 1.06 & $\begin{array}{c}.3 \\
1\end{array}$ & . & . & . & . & & \\
\hline & Openness $^{\mathrm{a}}$ & $\begin{array}{c}6.61 \\
(2.11)\end{array}$ & $6.96(1.74)$ & .63 & $\begin{array}{l}.1 \\
8\end{array}$ & . & . & . & . & & \\
\hline & Agreeableness $^{\mathrm{a}}$ & $\begin{array}{c}6.29 \\
(1.54)\end{array}$ & $6.92(1.20)$ & 1.56 & $\begin{array}{l}.4 \\
6\end{array}$ & . & . & . & . & & \\
\hline & $\begin{array}{l}\text { Emotional } \\
\text { stability }^{\mathrm{a}}\end{array}$ & $\begin{array}{c}5.97 \\
(1.40)\end{array}$ & $5.95(1.33)$ & -.04 & $\begin{array}{c}.0 \\
1\end{array}$ & . & . & . & . & & \\
\hline & Extraversion $^{\mathrm{a}}$ & $\begin{array}{c}5.80 \\
(2.32)\end{array}$ & $6.34(1.21)$ & .99 & $\begin{array}{l}.2 \\
9\end{array}$ & . & . & . & . & & \\
\hline EB & CBCL & $\begin{array}{c}9.47 \\
(6.85)\end{array}$ & $9.20(5.99)$ & .14 & $\begin{array}{l}.0 \\
4\end{array}$ & . & . & . & . & & \\
\hline \multirow[t]{2}{*}{ ТоM } & ToM Task Battery & $\begin{array}{c}8.48 \\
(2.00)\end{array}$ & $7.63(2.46)$ & -1.30 & $\begin{array}{l}.3 \\
8\end{array}$ & $\begin{array}{c}9.79 \\
(2.45)\end{array}$ & $9.62(2.20)$ & -.25 & .07 & .59 & .01 \\
\hline & ToMI & $\begin{array}{l}14.87 \\
(2.00)\end{array}$ & $14.89(2.65)$ & .03 & $\begin{array}{c}.0 \\
1\end{array}$ & $\begin{array}{l}16.24 \\
(1.81)\end{array}$ & $15.51(1.83)$ & -1.32 & .40 & 1.36 & .03 \\
\hline \multirow[t]{8}{*}{ SIP } & RES total & $\begin{array}{c}57.71 \\
(14.46)\end{array}$ & $\begin{array}{c}58.04 \\
(12.38)\end{array}$ & .09 & $\begin{array}{l}.0 \\
2\end{array}$ & $\begin{array}{c}71.96 \\
(11.49)\end{array}$ & $\begin{array}{c}82.04 \\
(12.61)\end{array}$ & $2.86^{* * *}$ & .84 & $8.54 * *$ & .16 \\
\hline & RES question 1 & $\begin{array}{l}23.58 \\
(3.91)\end{array}$ & $23.25(3.63)$ & -.31 & $\begin{array}{l}.0 \\
9\end{array}$ & $\begin{array}{l}26.35 \\
(2.39)\end{array}$ & $27.08(1.56)$ & 1.26 & .36 & 1.05 & .02 \\
\hline & RES question 2 & $\begin{array}{l}11.63 \\
(1.76)\end{array}$ & $11.96(1.49)$ & .71 & $\begin{array}{l}.2 \\
0\end{array}$ & $\begin{array}{l}12.30 \\
(1.69)\end{array}$ & $12.96(.99)$ & 1.62 & .48 & .28 & .01 \\
\hline & RES question 3 & $\begin{array}{c}22.50 \\
(10.76)\end{array}$ & $22.83(9.08)$ & .12 & $\begin{array}{l}.0 \\
3\end{array}$ & $\begin{array}{l}33.30 \\
(9.29)\end{array}$ & $\begin{array}{c}42.00 \\
(11.15)\end{array}$ & $2.90 * *$ & .85 & $9.10 * *$ & .17 \\
\hline & $\begin{array}{l}\% \text { of wrong/no } \\
\text { justification }\end{array}$ & $\begin{array}{c}38.39 \\
(16.96)\end{array}$ & $\begin{array}{c}41.67 \\
(16.67)\end{array}$ & .67 & $\begin{array}{l}.1 \\
9\end{array}$ & $\begin{array}{c}27.95 \\
(13.26)\end{array}$ & $\begin{array}{c}12.50 \\
(13.36)\end{array}$ & $\begin{array}{c}-3.98 * * \\
*\end{array}$ & $\begin{array}{c}1.1 \\
6\end{array}$ & $16.59 * * *$ & .27 \\
\hline & $\begin{array}{l}\% \text { of Descriptive } \\
\text { level }\end{array}$ & $\begin{array}{c}49.11 \\
(13.21)\end{array}$ & $\begin{array}{c}42.86 \\
(12.98)\end{array}$ & -1.65 & $\begin{array}{l}.4 \\
8\end{array}$ & $\begin{array}{c}42.24 \\
(13.43)\end{array}$ & $\begin{array}{c}46.43 \\
(18.60)\end{array}$ & .88 & .26 & 3.27 & .07 \\
\hline & $\begin{array}{l}\% \\
\text { Intersubjective } \\
\text { level }\end{array}$ & $\begin{array}{c}12.50 \\
(16.48)\end{array}$ & $\begin{array}{c}15.48 \\
(12.75)\end{array}$ & .70 & $\begin{array}{l}.2 \\
0\end{array}$ & $\begin{array}{c}27.64 \\
(12.80)\end{array}$ & $\begin{array}{c}40.18 \\
(19.51)\end{array}$ & $2.59 *$ & .76 & $4.01 *$ & .08 \\
\hline & $\begin{array}{l}\% \text { of Conceptual } \\
\text { level }\end{array}$ & 00 & 00 & .00 & 00 & $\begin{array}{c}2.17 \\
(3.99)\end{array}$ & $.89(2.41)$ & -1.34 & .39 & 1.79 & .04 \\
\hline \multirow{3}{*}{$\begin{array}{l}\text { Social } \\
\text { adjustmen } \\
t\end{array}$} & EASE Total & $\begin{array}{l}.79 \\
(.08)\end{array}$ & $.71(.17)$ & 1.70 & $\begin{array}{l}.6 \\
0\end{array}$ & $\begin{array}{l}.79 \\
(.14)\end{array}$ & $.75(.14)$ & .96 & .29 & 1.17 & .03 \\
\hline & EASE No ToM & $\begin{array}{c}.84 \\
(.07)\end{array}$ & $.77(.17)$ & -1.74 & $\begin{array}{l}.5 \\
4\end{array}$ & $\begin{array}{c}.86 \\
(.14)\end{array}$ & $.82(.14)$ & .89 & .21 & 1.17 & .03 \\
\hline & EASE ToM & $\begin{array}{l}.74 \\
(.11)\end{array}$ & $.67(.19)$ & -1.53 & $\begin{array}{l}.4 \\
5\end{array}$ & $\begin{array}{c}.72 \\
(.16)\end{array}$ & $.67(.16)$ & .90 & .31 & .82 & .02 \\
\hline \multirow[t]{3}{*}{$\begin{array}{l}\text { Family } \\
\text { measures }\end{array}$} & $\begin{array}{l}\text { Mothers' } \\
\text { education }(\max = \\
7)\end{array}$ & $\begin{array}{l}5.52 \\
(1.3)\end{array}$ & $4.41(1.53)$ & $\begin{array}{c}-2.62 \\
*\end{array}$ & $\begin{array}{l}.7 \\
8\end{array}$ & . & . & . & & & \\
\hline & $\begin{array}{l}\text { Fathers' education } \\
(\max =7)\end{array}$ & $\begin{array}{c}4.33 \\
(1.59)\end{array}$ & $4.30(1.75)$ & -.06 & $\begin{array}{l}.0 \\
2\end{array}$ & . & . & . & & & \\
\hline & $\begin{array}{l}\text { Family income } \\
(\max =9)\end{array}$ & $\begin{array}{c}6.05 \\
(2.01) \\
\end{array}$ & $5.75(1.80)$ & -.49 & $\begin{array}{l}.1 \\
6 \\
\end{array}$ & . & . & . & & & \\
\hline
\end{tabular}


Table 2. Pearson intercorrelations among social cognition measures at pre-test, social adjustment, and individual characteristics

\begin{tabular}{|c|c|c|c|c|c|c|c|c|c|c|c|c|c|c|c|c|}
\hline & Variable & 1 & 2 & 3 & 4 & 5 & 6 & 7 & 8 & 9 & 10 & 11 & 12 & 13 & 14 & 15 \\
\hline 1. & $\mathrm{CA}$ & - & $\begin{array}{c}-.16 \\
8\end{array}$ & $\begin{array}{c}-.333 \\
*\end{array}$ & $-.317 *$ & $\begin{array}{c}-.502 * \\
* *\end{array}$ & -.153 & -.086 & .138 & .207 & .038 & $\begin{array}{l}.616^{*} \\
* *\end{array}$ & .089 & .166 & $\begin{array}{c}-.11 \\
4\end{array}$ & -.069 \\
\hline 2. & WPPSI & & - & .247 & $\begin{array}{c}.541 * \\
* *\end{array}$ & $.310^{*}$ & $\begin{array}{c}.399^{*} \\
*\end{array}$ & .028 & -.079 & $\begin{array}{c}.393^{*} \\
*\end{array}$ & .192 & .177 & $\begin{array}{c}.400 * \\
*\end{array}$ & .177 & $\begin{array}{l}.330 \\
*\end{array}$ & $\begin{array}{c}.426^{*} \\
*\end{array}$ \\
\hline 3. & $\begin{array}{l}\text { Conscious } \\
\text { ness }^{\mathrm{a}}\end{array}$ & & & - & $\begin{array}{c}.687 * \\
* *\end{array}$ & $\begin{array}{c}.626^{* *} \\
*\end{array}$ & .119 & $\begin{array}{c}.588^{*} \\
* *\end{array}$ & $\begin{array}{c}-.647 * \\
* *\end{array}$ & -.017 & $\begin{array}{c}-.05 \\
4\end{array}$ & -.011 & -.018 & .180 & .151 & .182 \\
\hline 4. & Openness ${ }^{\mathrm{a}}$ & & & & - & $\begin{array}{c}.743 * * \\
*\end{array}$ & $\begin{array}{c}.579^{*} \\
* *\end{array}$ & .156 & $\begin{array}{c}-.386^{*} \\
*\end{array}$ & .285 & .238 & .144 & .210 & .160 & $\begin{array}{l}.316 \\
*\end{array}$ & $\begin{array}{c}.409 * \\
*\end{array}$ \\
\hline 5. & $\begin{array}{l}\text { Agreeable } \\
\text { ness }^{\mathrm{a}}\end{array}$ & & & & & - & $\begin{array}{c}.398^{*} \\
*\end{array}$ & $.303^{*}$ & $-.352 *$ & .115 & .021 & -.119 & -.040 & .021 & .119 & .213 \\
\hline 6. & $\begin{array}{l}\text { Extraversi } \\
\text { on }^{\mathrm{a}}\end{array}$ & & & & & & - & $-.302 *$ & .230 & .282 & $\begin{array}{c}.311 \\
*\end{array}$ & .286 & $.312 *$ & .057 & .252 & $\begin{array}{c}.405 * \\
*\end{array}$ \\
\hline 7. & $\begin{array}{l}\text { Emotional } \\
\text { stability }^{\mathrm{a}}\end{array}$ & & & & & & & - & $\begin{array}{c}-.536^{*} \\
* *\end{array}$ & -.096 & $\begin{array}{c}-.23 \\
0\end{array}$ & -.161 & -.233 & .142 & $\begin{array}{c}-.10 \\
1\end{array}$ & -.106 \\
\hline 8. & $\begin{array}{l}\text { CBCL } \\
\text { (EB) }\end{array}$ & & & & & & & & - & -.102 & .236 & -.002 & .073 & -.180 & .011 & -.101 \\
\hline & $\begin{array}{l}\text { ToM Task } \\
\text { Battery }\end{array}$ & & & & & & & & & - & $\begin{array}{c}.339 \\
*\end{array}$ & .251 & $\begin{array}{c}.463 * \\
*\end{array}$ & .294 & .162 & .303 \\
\hline & ToMI & & & & & & & & & & - & .249 & $\begin{array}{l}.607 * \\
* *\end{array}$ & .065 & .258 & .264 \\
\hline 11. & RES & & & & & & & & & & & - & .160 & .185 & $\begin{array}{c}-.01 \\
1\end{array}$ & .137 \\
\hline 12. & EASE & & & & & & & & & & & & - & $\begin{array}{c}.431^{*} \\
*\end{array}$ & $\begin{array}{c}.336 \\
*\end{array}$ & $\begin{array}{c}.416^{*} \\
*\end{array}$ \\
\hline & $\begin{array}{l}\text { Mothers' } \\
\text { education }\end{array}$ & & & & & & & & & & & & & - & $\begin{array}{l}.379 \\
*\end{array}$ & $\begin{array}{c}.450 * \\
*\end{array}$ \\
\hline & $\begin{array}{l}\text { Fathers' } \\
\text { education }\end{array}$ & & & & & & & & & & & & & & - & $\begin{array}{c}.431 * \\
*\end{array}$ \\
\hline 15. & $\begin{array}{l}\text { Family } \\
\text { income }\end{array}$ & & & & & & & & & & & & & & & - \\
\hline
\end{tabular}

Table 3. Summary of significant multiple regression analyses on predictors of social cognition measures and social adjustment in post-test

\begin{tabular}{|c|c|c|c|c|c|c|c|c|c|c|c|c|c|c|c|c|}
\hline & \multicolumn{4}{|c|}{ ToM Task Battery (ToM) } & \multicolumn{4}{|c|}{ ToMI (ToM) } & \multicolumn{4}{|c|}{ RES (SIP) } & \multicolumn{4}{|c|}{ EASE ( Social adjustment) } \\
\hline Predictors & $\beta$ & $\begin{array}{c}\Delta \mathrm{AR} \\
2\end{array}$ & $\begin{array}{l}\text { Tot } \\
\mathrm{R}^{2} \\
\end{array}$ & $F$ & $\beta$ & $\begin{array}{c}\Delta \mathrm{R} \\
2\end{array}$ & $\begin{array}{l}\text { Tot } \\
\mathrm{R}^{2} \\
\end{array}$ & $F$ & $\beta$ & $\Delta \mathrm{R}^{2}$ & $\begin{array}{l}\text { Tot } \\
\mathrm{R}^{2} \\
\end{array}$ & $F$ & $\beta$ & $\Delta \mathrm{R}^{2}$ & $\begin{array}{l}\text { Tot } \\
\mathrm{R}^{2} \\
\end{array}$ & $F$ \\
\hline Model 1 & & .15 & $.15^{*}$ & $7.66^{*}$ & & .51 & $.51 * *$ & 42.53 & & $.26^{*}$ & $.26^{*}$ & $20.5^{*}$ & & $.47 *$ & $.47 *$ & 34.24 \\
\hline $\begin{array}{l}\text { Pre-test } \\
\text { results }\end{array}$ & $\begin{array}{l}.38^{*} \\
*\end{array}$ & * & * & $*$ & $\begin{array}{l}.72 * \\
*\end{array}$ & * & * & $* *$ & $\begin{array}{l}.56^{*} \\
*\end{array}$ & * & * & * & $\begin{array}{l}.68 * \\
*\end{array}$ & * & * & $* *$ \\
\hline Model 2 & & .24 & .39 & $2.90 *$ & & .14 & .66 & $7.92 *$ & & .11 & .36 & $3.32 *$ & & $.25^{*}$ & $.71^{*}$ & $9.97 *$ \\
\hline $\begin{array}{l}\text { Pre-test } \\
\text { results }\end{array}$ & $\begin{array}{l}.12 \\
.33 *\end{array}$ & & & $*$ & $\begin{array}{l}.73 * \\
*\end{array}$ & & & * & $\begin{array}{l}.52^{*} \\
.03\end{array}$ & & & & $\begin{array}{l}.60^{*} \\
*\end{array}$ & & & \\
\hline $\mathrm{CA}$ & $.38 *$ & & & & .14 & & & & .13 & & & & $.30 *$ & & & \\
\hline IQ & .02 & & & & .29 & & & & .38 & & & & .05 & & & \\
\hline Conscious & .09 & & & & $.54 *$ & & & & -.57 & & & & .01 & & & \\
\hline ness & -.00 & & & & $*$ & & & & -.09 & & & & .29 & & & \\
\hline Openness & .08 & & & & -.33 & & & & .28 & & & & $.45^{*}$ & & & \\
\hline Agreeable & -.19 & & & & -.02 & & & & -.03 & & & & $*$ & & & \\
\hline ness & & & & & -.18 & & & & & & & & -.31 & & & \\
\hline Extraversi & & & & & -.26 & & & & & & & & $*$ & & & \\
\hline on & & & & & & & & & & & & & -.22 & & & \\
\hline $\begin{array}{l}\text { Emotional } \\
\text { Stability }\end{array}$ & & & & & & & & & & & & & & & & \\
\hline Model 3 & & .01 & .40 & $2.61^{*}$ & & .03 & .69 & $7.86^{*}$ & & $.24 *$ & $.60 *$ & $6.00 *$ & & .00 & .72 & $8.78^{*}$ \\
\hline Pre-test & .13 & & & & $.74 *$ & & & $*$ & $.37 *$ & $*$ & $*$ & * & $.58^{*}$ & & & $*$ \\
\hline results & $.33^{*}$ & & & & * & & & & .21 & & & & * & & & \\
\hline CA & $.41 *$ & & & & .12 & & & & .26 & & & & $.29 *$ & & & \\
\hline IQ & -.01 & & & & .24 & & & & .30 & & & & * & & & \\
\hline Conscious & .11 & & & & $.59 *$ & & & & -.42 & & & & .03 & & & \\
\hline ness & -.03 & & & & * & & & & -.21 & & & & .03 & & & \\
\hline Openness & .05 & & & & -.38 & & & & .17 & & & & .28 & & & \\
\hline Agreeable & -.18 & & & & .04 & & & & .02 & & & & $.47 *$ & & & \\
\hline ness & & & & & .14 & & & & & & & & * & & & \\
\hline Extraversi & .11 & & & & .27 & & & & $.49 *$ & & & & -.29 & & & \\
\hline on & & & & & & & & & * & & & & -.23 & & & \\
\hline Emotional & & & & & -.20 & & & & & & & & & & & \\
\hline Stability & & & & & & & & & & & & & -.08 & & & \\
\hline $\begin{array}{l}\text { Group } \\
\text { condition }\end{array}$ & & & & & & & & & & & & & & & & \\
\hline
\end{tabular}


Notes. $\mathrm{CA}=$ chronological age, $\mathrm{IQ}=$ Intellectual Quotient, $\beta=$ regression coefficient, $\Delta \mathrm{R}^{2}=\mathrm{R}$ squared change, Tot $\mathrm{R}^{2}=$ Total R squared, $* p<.05, * * p<.01, * * * p \leq .00$.

\section{Discussion}

As predicted (1a), this study demonstrates some positive effects of middle-term training in social cognition (as for example Ornaghi et al., 2014; Shure \& Spivack, 1982; Webster-Stratton \& Reid, 2008). As Houssa and colleagues (2014) reported about a one-shot training session, training that involves feedback and explanations improved children's performances in social cognition. With regard to repeated measures analyses, the only significant difference concerns performances in social problem solving in favor of the experimental group. This could be due to the fact that SIP sessions were more effective than ToM sessions, but also because ToM sessions were given in the first part of the training. These results could also be due to the children's spontaneous development in both groups (there were approximately 5 months between pre- and post-test).

Like some authors (Begeer et al., 2011) who found no strong evidence for the effectiveness of ToM training on mind-reading skills, we failed to find any significant difference in the ToM Task Battery score. However, those authors found effects in some ToM skills (conceptual ToM skills) only (with 8-13-year-old children), which was not the case in our study, probably due to the age difference.

These different effects between ToM and SIP variables could be interpreted with reference to the different underlying theoretical models. The RES refers to the SIP model, proposing a functional approach to social problem solving, whereas the ToM Task Battery is founded on the ToM model, which takes a developmental approach to the comprehension of mental states, which is seen as a lengthy process. As mentioned earlier, children may have benefited more from one part of the social cognition training than from another.

For the social problem solving, each step of the SIP model was covered during training sessions. Our training sessions led to improvements in several steps of the SIP model. For instance, in pre-test, children tended to justify their answers at a descriptive level, or produced a wrong/no answer. In post-test, the trained children provided fewer wrong/no answers and more intersubjective explanations. It shows that this intervention allowed children to improve their competences in social reasoning by taking a position linked to their better social awareness, as suggested by Lachavanne and Barisnikov (2013). Probably because the conceptual level of justification generally emerges later in development (Lachavanne \& Barisnikov, 2013), the trained children used hardly any conceptual justification in the RES. In preschoolers, focusing training sessions on the intersubjective level is effective because it matches children's zone of proximal development.

Concerning the social adjustment measure (1b), the trained group showed a significant difference between pre- and post-test for one scale of social adjustment (EASE non-ToM). Children who received training in social cognition were perceived as having better social skills and as adhering more closely to social rules in daily life. Such results are consistent with observations made by other authors (e.g. Domitrovich et al., 2007; Shure \& Spivack, 1982) who have reported an increase in social adjustment after training. Training in small groups fosters social relationships and adaptive interpersonal skills (Lachavanne \& Barisnikov, 2013).

The present study supports previous findings showing correlations among social cognition variables, social adjustment, some factors of personality and EB scores (Nader-Grosbois, Houssa, \& Mazzone, 2013). Positive correlations were obtained between social cognition measures. As Hutchins and colleagues (2012) found, ToM Task Battery and ToMI are positively correlated, meaning that the better children's competences in solving ToM tasks, the more their parents perceive them as having good ToM abilities in daily life situations (and vice versa).

As predicted (2a), several individual characteristics were significantly linked with social cognition or social adjustment measures. As children grow older, they acquire competences in social cognition. The higher children's IQ is, the more positive their parents' perception of their social adjustment. In particular, ToM Task Battery was correlated with IQ, whereas the RES was correlated with CA. However, the indirect measure ToMI did not correlate with CA or IQ. We also observed a significant positive correlation between IQ and social adjustment. This means that, as children increased their IQ through real-life experience, caregivers perceived them as better socially adjusted.

As hypothesized (2b), the more children were perceived as being extroverted, the more they were perceived as being socially adapted (and vice versa) (Meunier et al., 2011).

As predicted (2c), positive and significant correlations were obtained between ToM Task Battery, ToMI and social adjustment. This means that the better children performed in ToM, the more they were perceived as socially well adapted by their parents (and vice versa) (Denham \& Burton, 2003; Houssa, Nader-Grosbois, et al., 2014; Nader-Grosbois et al., 2013). Contrary to what was expected (2d), we did not observe any correlation between social cognition measures and CA and EB. This could be due to the fact that the inter-individual variability in CBCL was low 
in typically developing preschoolers; it could be different in children diagnosed as presenting EB disorders. Finally, as in previous studies, significant correlations were found between EB and four personality factors (2d) (Meunier et al., 2011; Prinzie et al., 2003). These correlations mean that children were perceived as having more EB when they were perceived as being less conscious, open, agreeable and emotionally stable.

Multiple regression analyses showed that the training had no significant effect on post-test performance for ToM measures. This result was congruent with previous analyses. In the SIP measure, we showed that group condition was a significant predictor of the post-test result. This means that the training had an effect on performance, because experimental group improved significantly more than control group. Again, this result allows us to conclude that the training is effective in improving SIP abilities. However, individual characteristics did not influence the post-test performance. This means that different profiles of children were receptive to training sessions. Finally, concerning social adjustment, several personality factors had some impact on post-test results. Teachers' perception of children's extraversion and agreeableness predicted parents' perception of children's social adjustment.

\section{Implications for Research and Intervention}

In summary, as Houssa and colleagues (2014) showed, the pre- and post-test batteries differentiated between socio-cognitive profiles accurately and could be used to detect weaknesses in preschoolers and to better understand social (mal)adjustment. This study could help professionals and parents by providing them some basis for early training exercises that can induce an improvement in SIP competences in preschoolers. One limitation of the present study is that we should have taken measures at the middle of the intervention, to test the potential effect on ToM measures, after ToM sessions. We decided not to do this in order to avoid a learning effect or familiarity effect related to ToM tasks in children, which might have introduced a bias in performance or a decreasing of motivation in the post-test. To counteract, we should have reversed the order of ToM and SIP sessions for half of groups.

Further studies are needed to compare different samples of atypical children, in order to test whether improvements after social cognition training are similar. It could be relevant to test this training in EB children, in order to determine whether it is possible to reduce their social cognition difficulties and their EB and to increase their social adjustment.

\section{Acknowledgements}

The authors wish to thank Tiffany Hutchins, David Schultz and Yair Ziv for their materials.

We are also grateful to the children, parents, and teachers for their cooperation.

This project was financially supported by a concerted research action on externalizing behavior (Convention ARC 11/16-038).

\section{References}

Achenbach, T. М. (1991). Manual for the CBCL/4-18 and 1991 Profile.

Achenbach, T. M., \& Rescorla, L. A. (2000). Manual for the ASEBA Preschool Forms \& Profiles. Burlington, VT: University of Vermont, Research Center for Children, Youth, \& Families.

Appleton, M., \& Reddy, V. (1996). Teaching three year-olds to pass false belief tests: A conversational approach. Social Development, 5, 275-291. http://dx.doi.org/10.1111/j.1467-9507.1996.tb00086.x

Astington, J. W. (1996). Theory of Mind goes to school. Educational Leadership, 56(3), 46-48.

Barisnikov, K., Van der Linden, M., \& Hippolyte, L. (2004). Tâche de résolution sociale. Manuel inédit. Genève.

Begeer, S., Gevers, C., Clifford, P., Verhoeve, M., Kat, K., Hoddenbach, E., \& Boer, F. (2011). Theory of Mind Training in Children with Autism: A randomized controlled trial. Journal of autism and developmental disorders, 41, 997-1006. http://dx.doi.org/10.1007/s10803-010-1121-9

Bhavnagri, N. P., \& Samuels, B. G. (1996). Children's literature and activities promoting social cognition of peer relationships in preschoolers. early Childhood Research Quarterly, 11, 307-331. doi: http://dx.doi.org/10.1016/S0885-2006(96)90010-1

Blair, R. J. R., \& Coles, M. (2000). Expression recognition and behavioural problems in early adolescence. cognitive development, 15, 421-434. http://dx.doi.org/10.1016/S0885-2014(01)00039-9

Crick, N. R., \& Dodge, K. A. (1994). A review and reformulation of social information-processing mechanisms in children's social adjustment. Psychological Bulletin, 115(1), 74-101. http://dx.doi.org/10.1037/0033-2909.115.1.74

Crick, N. R., \& Dodge, K. A. (1996). Social information-processing mechanisms in reactive and proactive aggression. Child Development, 67, 993-1002. http://dx.doi.org/10.2307/1131875 
Deneault, J., \& Ricard, M. (2013). Are emotion and mind understanding differently linked to young children's social adjustment? Relationships between behavioral consequences of emotions, false belief, and SCBE. The journal of Genetic Psychology, 174(1), 88-116. http://dx.doi.org/10.1080/00221325.2011.642028

Denham, S. A., Blair, K. A., DeMulder, E., Levitas, J., Sawyer, K., Auerbach-Major, S., \& Queenan, P. (2003). Preschool emotional competence: Pathway to social competence? Child Development, 74(1), 238-256. http://dx.doi.org/10.1111/1467-8624.00533

Denham, S. A., \& Burton, R. (2003). Social and emotional prevention and intervention programming for preschoolers. New York: Kluwer-Plenum.

Dodge, K. A., \& Crick, N. R. (1990). Social information-processing bases of aggressive behaviour in children. Personality and Social Psychology Bulletin, 16, 8-22. http://dx.doi.org/10.1177/0146167290161002

Dodge, K. A., Lansford, J. E., Burks, V. S., Bates, J. E., Pettit, G. S., Fontaine, R., \& Price, J. M. (2003). Peer rejection and social information-processing factors in the development of aggressive behavior problems in children. Child Development, 74(2), 374-393. http://dx.doi.org/10.1111/1467-8624.7402004

Dodge, K. A., \& Pettit, G. S. (2003). A biopsychosocial model of the development of chronic conduct problems in adolescence. Developmental Psychology, 39(2), 349-371. http://dx.doi.org/10.1037/0012-1649.39.2.349

Domitrovich, C. E., Cortes, R. C., \& Greenberg, M. T. (2007). Improving young children's social and emotional competence: A randomized trial of the preschool "PATHS" curriculum. Journal of Primary Prevention, 28(2), 67-91. http://dx.doi.org/10.1007/s10935-007-0081-0

Eisenberg, N., Fabes, R. A., Shepard, S. A., Murphy, B. C., Guthrie, I. K., Jones, S., \& Maszk, P. (1997). Contemporaneous and longitudinal prediction of children's social functioning from regulation and emotionality. Child Development, 68, 642-664. http://dx.doi.org/10.2307/1132116

Fahie, C. M., \& Symons, D. K. (2003). Executive functioning and theory of mind in children clinically referred for attention and behavior problems. Applied Developmental Psychology, 24, 51-73. http://dx.doi.org/10.1016/S0193-3973

Frey, K. S., Hirschstein, M. K., \& Guzzo, B. A. (2000). Second Step: Preventing Aggression by Promoting Social Competence. Journal of Emotional \& Behavioral Disorders, 8(2). http://dx.doi.org/10.1177/106342660000800206

Hadwin, J., Baron-Cohen, S., Howlin, P., \& Hill, K. (1996). Can we teach with autism to understand emotions, belief, or pretence? Development and Psychopathology, 8, 345-365. http://dx.doi.org/10.1017/S0954579400007136

Hippolyte, L., Iglesias, K., Van der Linden, M., \& Barisnikov, K. (2010). Social reasoning skills in adults with Down syndrome: the role of language, executive functions and socio-emotional behaviour. Journal of Intellectual Disability Research, 54(8), 714-726. http://dx.doi.org/10.1111/j.1365-2788.2010.01299.x

Houssa, M., Mazzone, S., \& Nader-Grosbois, N. (2014). Validation d'une version francophone de l'Inventaire de la Théorie de l'Esprit. Revue européenne de psychologie appliquée, 64(4), 169-179. http://dx.doi.org/10.1016/j.erap.2014.02.002

Houssa, M., Nader-Grosbois, N., \& Jacobs, E. (2014). Experimental study of short term training in social cognition in typically developing preschoolers. Journal of Education and Training Studies, 2(1), 139-154.

Howlin, P., Baron-Cohen, S., \& Hadwin, J. (2011). Apprendre aux enfants autistes à comprendre la pensée des autres.

Hughes, C., Dunn, J., \& White, A. (1998). Trick or treat? : Uneven understanding of mind and emotion and executive dysfunction in hard-to-manage preschoolers (English). Journal of child psychology and psychiatry and allied disciplines (Print), 39(7), 981-994. http://dx.doi.org/10.1111/1469-7610.00401

Hughes, C., Soares-Boucaud, I., Hochman, J., \& Frith, U. (1997). Social behavior in pervasive developmental disorders: effects of informant, group and "theory of mind". European Child and Adolescent Psychiatry, 6, 191-198. http://dx.doi.org/10.1007/BF00539925

Hutchins, T. L., Prelock, P. A., \& Bonazinga, L. A. (2012). Psychometric evaluation of the theory of mind inventory (ToMI): A study of typically developing children and children with autism spectrum disorder. Journal of autism and developmental disorders, 42, 327-341. http://dx.doi.org/10.1007/s10803-011-1244-7

Hutchins, T. L., Prelock, P. A., \& Chace, W. (2008). Test-retest reliability of a theory of mind task battery for children with autism spectrum disorders. Focus on autism and other developmental disabilities, 23(4), 195-206. http://dx.doi.org/10.1177/1088357608322998 
Izard, C. E., King, K. A., Trentacosta, C. J., Morgan, J. K., Laurenceau, J. C., Krauthamer-Ewing, E. S., \& Finlon, K. J. (2008). Accelerating the development of emotion competence in head start children: Effects on adaptative and maladaptative behavior. Development and Psychopathology, 20, 369-397. http://dx.doi.org/10.1017/S0954579408000175

Lachavanne, A., \& Barisnikov, K. (2013). Rééducation des compétences socio-émotionnelles pour des adultes présentant une déficience intellectuelle. Revue européenne de psychologie appliquée, 63, 345-352. http://dx.doi.org/10.1016/j.erap.2013.09.002

Lecce, S., Bianco, F., Devine, R. T., Hughes, C., \& Banerjee, R. (2014). Promoting theory of mind during middle childhood: A training program. Journal of Experimental Child Psychology, 126, 52-67. http://dx.doi.org/10.1016/j.jecp.2014.03.002

Merrell, K. W., Juskelis, M. P., Tran, O. K., \& Buchanan, R. (2008). Social and emotional learning in the classroom: Evaluation of Strong Kids and Strong Teens on student's social-emotional knowledge and symptoms. Journal of Applied School Psychology, 24(2), 209-224. http://dx.doi.org/10.1080/15377900802089981

Meunier, J. C., Roskam, I., Stievenart, M., Van de Moortele, G., Browne, D. T., \& Kumar, A. (2011). Externalizing behavior trajectories : The role of parenting, sibling relationships and child personality. Journal of Applied Developmental Psychology, 32, 20-33. http://dx.doi.org/10.1016/j.appdev.2010.09.006

Nader-Grosbois, N., Houssa, M., \& Mazzone, S. (2013). How could theory of mind contribute to the differentiation of social adjustment profiles of children with externalizing behavior disorders and children with intellectual disabilities? Research in Developmental Disabilities, 34, 2642-2660. http://dx.doi.org/10.1016/j.ridd.2013.05.010

Ornaghi, V., Brockmeier, J., \& Grazzani, I. (2014). Enhancing social cognition by training children in emotion understanding: A primary school study. Journal of Experimental Child Psychology, 119, 26-39. http://dx.doi.org/10.1016/j.jecp.2013.10.005

Pears, K. C., Fisher, P. A., \& Bronz, K. D. (2007). An intervention to promote social emotional school readiness in foster children: Preliminary outcomes from a pilot study. School Psychological Review, 36(4), 665-673.

Pettit, G. S., Dodge, K. A., \& Brown, M. M. (1988). Early family experience, social problem solving patterns, and children's social competence. Child Development, 59, 107-120. http://dx.doi.org/10.2307/1130393

Prinzie, P., Onghena, P., Hellinckx, W., Grietens, H., Ghesquière, P., \& Colpin, H. (2003). The additive and interactive effects of parenting and children's personality on externalizing behaviour. European Journal of Personality, 17, 95-117. http://dx.doi.org/10.1002/per.467

Roskam, I., De Maere-Gaudissart, A., \& Vandenplas-Holper, C. (2000). Mise au point d'un instrument d'évaluation de la personnalité des enfants à partir du Modèle à Cinq Facteurs. L'orientation scolaire et professionnelle, 29(4), 661-672.

Shure, M. B., \& Spivack, G. (1982). Interpersonal problem-solving in young children: A cognitive approach to prevention. American Journal of Community Psychology, 10(3), 341-356. http://dx.doi.org/10.1007/BF00896500

Vygotsky, I. S. (1978). Mind in Society. The development of higher psychological processes. Cambridge: Harvard University Press.

Walker, S. (2005). Gender Differences in the Relationship Between Young Children's Peer-Related Social Competence and Individual Differences in Theory of Mind. Journal of Genetic Psychology, 166(3), 297-312. 10.3200/gntp.166.3.297-312

Webster-Stratton, C., \& Reid, J. (2008). Adapting the incredible years child dinosaur social, emotional, and problem-solving intervention to address comorbid diagnoses. Journal of Children's Services, 3, 17-30. http://dx.doi.org/10.1108/17466660200800016

Wellman, H. M. (1991). From desires to beliefs: acquisition of a theory of mind. In A. Whiten (Ed.), Natural theories of mind (pp. 19-38). Cambridge, MA: Basil Blackwell.

Weschler, D. (2004). WPPSI-III: Manuel d'interprétation. Paris: Les Editions du Centre de Psychologie Appliquée.

Yeates, K. O., Dennis, M., Rubin, K. H., Taylor, H. G., Bigler, E. D., Gerhardt, C. A., \& Vannatta, K. (2007). Social outcomes in childhood brain disorder: A heuristic integration of social neuroscience and developmental psychology. Psychological Bulletin, 133, 535-556. http://dx.doi.org/10.1037/0033-2909.133.3.535 


\section{Appendix}

Presentation of the objectives, activities, material and the techniques of each ToM session

\begin{tabular}{|c|c|c|c|}
\hline Session & ces (general terms) & Specific objectives (specific terms) and activities & Techniques \\
\hline $\begin{array}{l}\text { 1. How } \\
\text { I feel? }\end{array}$ & $\begin{array}{l}\text { - Discover my own emotions } \\
\text { - How do I express what I feel? } \\
\text { - Discover what the other person feels by } \\
\text { what he expresses } \\
\text { ToM emotion (Howlin): } 1 \text { and } 2\end{array}$ & $\begin{array}{l}\rightarrow \text { Identify own and others' emotions (posture, } \\
\text { voice and face) } \\
\rightarrow \text { Expression of emotions } \\
\rightarrow \text { Characteristics of emotions }\end{array}$ & \multirow{9}{*}{ 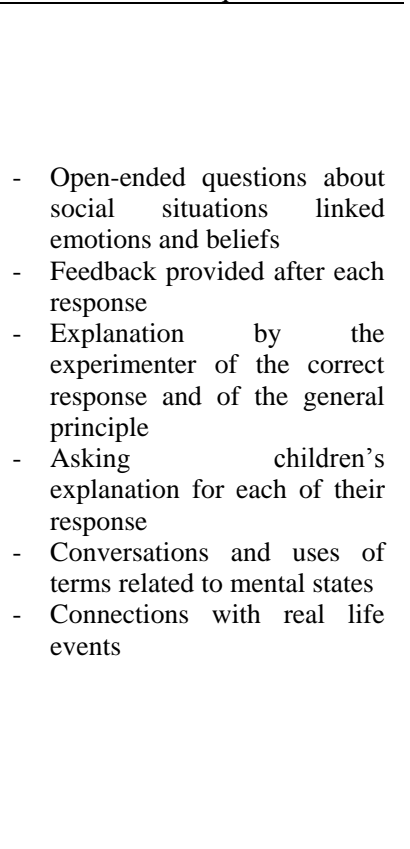 } \\
\hline $\begin{array}{l}\text { 2. What } \\
\text { do I I } \\
\text { believe? }\end{array}$ & $\begin{array}{l}\text { - Discover what I believe } \\
\text { - How do I express what I believe? } \\
\text { - Why do others not believe the same as me? } \\
\text { ToM belief (Howlin): } 1,2 \text { and } 3\end{array}$ & \multirow{7}{*}{$\begin{array}{l}\text { - Identify beliefs } \\
\text { - Be conscious of own and others' FB } \\
\rightarrow \text { A/R, perspective taking } \\
\text { - Identify causes of emotions } \\
\text { - Identify causes of others' emotions and attribution } \\
\text { - Identify causes of own emotions } \\
\text { - Identify causes of others' emotions and attribution } \\
\text { - Understand that everybody does not feel the same } \\
\text { - Identify beliefs } \\
\text { - Be conscious of own and others' FB: } \\
\rightarrow \text { Location change, unexpected content, deceptive } \\
\text { skills } \\
\text { - Identify consequences of own and others' } \\
\text { emotions }\end{array}$} & \\
\hline $\begin{array}{l}\text { 3. Why } \\
\text { this }\end{array}$ & $\begin{array}{l}\text { - Discov } \\
\text { - Discov }\end{array}$ & & \\
\hline feeling? & $\underline{T o M e l}$ & & \\
\hline $\begin{array}{l}\text { 4. Why } \\
\text { this }\end{array}$ & $\begin{array}{l}\text { - Discc } \\
\text { - Disce }\end{array}$ & & \\
\hline feeling? & $\underline{T o M}$ & & \\
\hline $\begin{array}{l}5 . \mathrm{Me} \\
\text { and my } \\
\text { beliefs }\end{array}$ & $\begin{array}{l}\text { ieve } \\
\text { hat I believe? } \\
\text { elieve the same as me? } \\
3,4 \text { and } 5\end{array}$ & & \\
\hline $\begin{array}{l}\text { 6. How } \\
\text { to react } \\
\text { after a } \\
\text { feeling? }\end{array}$ & $\begin{array}{l}\text { hen I feel } \\
\text { act when they feel } \\
4 \text { and } 5\end{array}$ & & \\
\hline $\begin{array}{l}\text { 7. Me } \\
\text { and my } \\
\text { beliefs }\end{array}$ & $\begin{array}{l}\text { - Discover what I believe } \\
\text { - How do I express what I believe? } \\
\text { - Why do others not believe the same as me? } \\
\text { ToM belief (Howlin) : } 1,2,3,4, \text { and } 5\end{array}$ & $\begin{array}{l}\text { - Identify beliefs } \\
\text { - Be conscious of own and others' FB } \\
\rightarrow \text { Exploration without help of each task of ToM } \\
\text { belief }\end{array}$ & \\
\hline
\end{tabular}
Presentation of the objectives, activities, material and the techniques of each SIP session

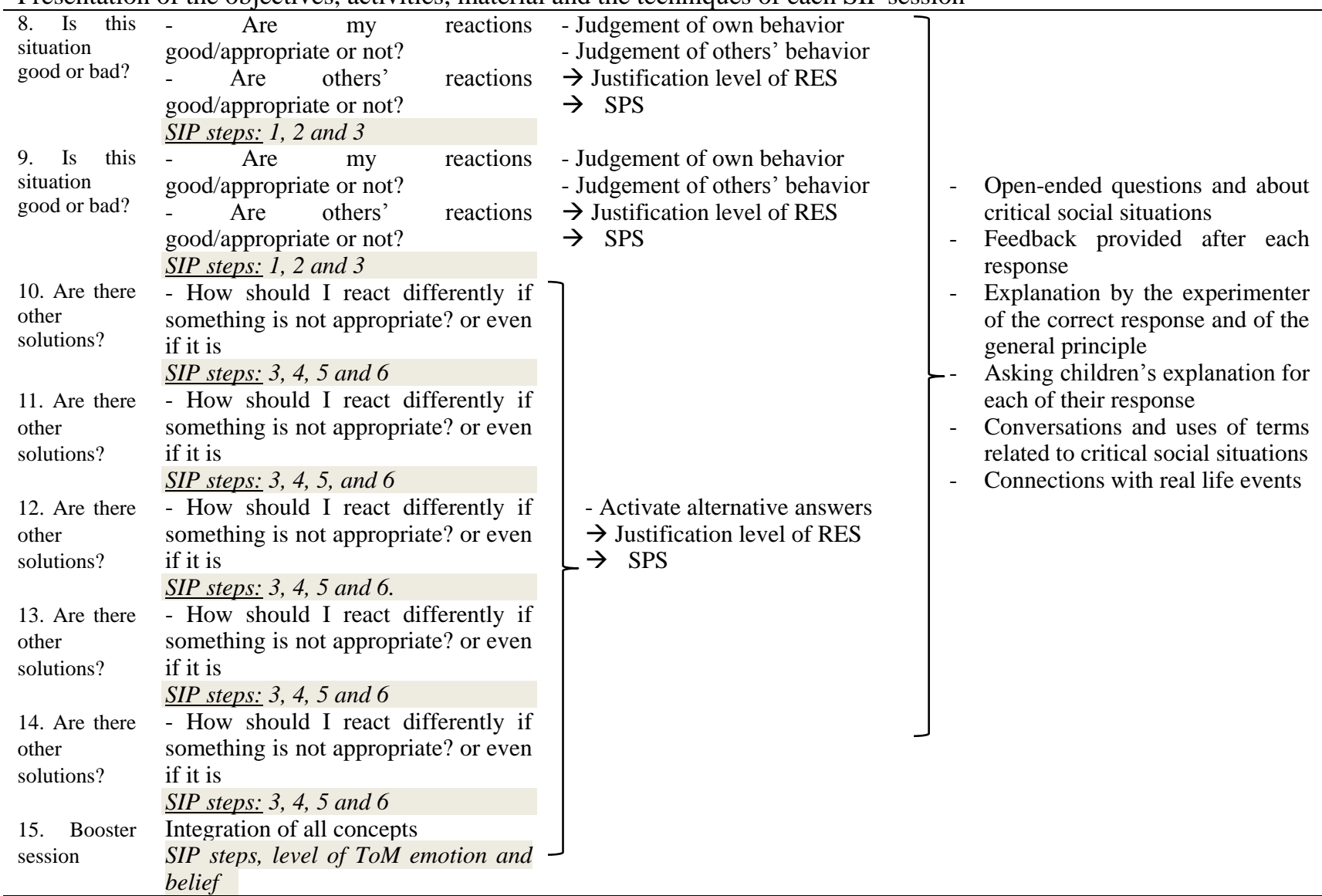

This work is licensed under a Creative Commons Attribution 3.0 License. 